\title{
Quality characteristics and antioxidant activites of 'Chuwhangbae' ( $P$. pyrifolia Nakai) dried with different methods
}

\author{
YoSup Park ${ }^{1}$, Han Chan Lee ${ }^{2}$, Yoon-Kyeong Kim ${ }^{3}$, Sam-Seok Kang ${ }^{2}$, \\ SooHyun Kang ${ }^{2}$, Byulhana Lee ${ }^{2 *}$ \\ ${ }^{1}$ Citrus Research Institute, National Institute of Horticulatural and Herbal Science, Rural Development Administration, \\ Jeju 63607, Korea \\ ${ }^{2}$ Pear Research Institute, National Institute of Horticulatural and Herbal Science, Rural Development Administration, \\ Naju 58216, Korea \\ ${ }^{3}$ Technology Cooperation Bureau, Rural Development Administration, Jeonju 54875, Korea
}

\section{건조 방법에 따른 ‘추황배’ 건조과일의 품질 특성 및 항산화 활성}

\author{
박요섭 ${ }^{1}$ - 이한찬 ${ }^{2}$ 김윤경 ${ }^{3}$ - 강삼석 ${ }^{2}$ - 강수현 ${ }^{2}$ - 이별하나 ${ }^{2 *}$ \\ ${ }^{1}$ 농촌진흥청 국립원예특작과학원 감귤연구소, ${ }^{2}$ 농촌진흥청 국립원예특작과학원 배연구소, \\ 3농촌진흥청 기술협력국
}

\begin{abstract}
This study was to prepare the pear-dried fruit for revitalizing the pear fruit industry, measuring the fruit quality characteristics and antioxidant activity according to different drying methods for both normal and physiological disorder fruit. The moisture content was significantly decreased with the lower in drying temperature. The $L^{*}$ value of freeze-drying, while $\mathbf{a}^{*}$ and $\mathbf{b}^{*}$ value were hot-air and vacuum drying were the greatest, leading to slight browning with yellow color. The soluble sugar content had the highest sucrose content in hot-air and freeze-drying, and fructose was found highest in vacuum drying. The total polyphenol content was found to decrease with increasing drying temperature, but the total flavonoid content did not differ according to the drying method. Four phenolic compounds were detected, namely, arbutin, catechin, chlorogenic acid, and gallic acid; fruits dried using hot-air drying had greater contents of these compounds than fruit treated with the other drying methods. Although there was no difference in the quality of dried fruit production using physiological disorder fruit, it would have to be used as a component of processed food as the area of disorder part was clearly brown. Also, because the effects on colors, ingredients, and texture vary depending on the drying method, which can be used to produce dried fruits that can be stored for a long period of time.
\end{abstract}

Key words : freeze-dry, hot-air dry, vacuum dry, phenolic compound

서 론

건조는 식품을 보존하기 위한 아주 오래된 방법 중 하나로 오늘날에도 널리 사용되고 있다. 건조는 식품에 존재하는 수분을 제거하여 장기간 보관 가능하게 하고, 섭취가 편리하
며 간식이나 요리의 부재료로 활용이 가능하다. 특히, 건조 된 과일은 수분이 제거되어 높은 밀도의 영양성분 및 식이섬 유를 가지며, 생과와 마찬가지로 항산화 활성(antioxidant activity)을 보인다고 알려져 있다. 높은 항산화 활성은 주로 과일 건조 시 농도가 증가되는 페놀화합물과 Maillard

*Corresponding author. E-mail : star118@korea.kr, Phone :+82-61-330-1563, Fax :+82-61-330-1533

Received 02 October 2019; Revised 08 November 2019; Accepted 22 November 2019.

Copyright (C) The Korean Society of Food Preservation.

This is an Open Access article distributed under the terms of the Creative Commons Attribution Non-Commercial License (http://creativecommons.org/licenses/by-nc/4.0) which permits unrestricted non-commercial use, distribution, and reproduction in any medium, provided the original work is properly cited. 
reaction product(MRP)의 잠재적 발생으로부터 기인된다 (Bennett 등, 2011; Youn과 Kim, 2012; Piscopo 등, 2014). 식품의 인공건조에는 열풍, 동결 및 감압건조 등 여러 방법이 존재하나 일반적으로 열을 가해 가열된 공기를 강제 대류시키는 열풍건조 방법이 사용되고 있다. 열풍건 조는 건조시간이 빠르고 비교적 경제적이며, 열풍건조 시 열처리가 병원균과 박테리아를 감소 및 파괴하는 동시에 효소를 비활성화시켜 식품 자체의 안정성을 증가시켜 저 장 수명을 연장한다(Lee 등, 2014; Piscopo 등, 2014). 그러 나 빠른 수분 손실로 인해 갈변, 수축 및 표면경화 등이 유발되어 품질에 부정적인 영향을 미칠 수 있다(Kim 등, 2011; Kim 등, 2014). 동결건조는 식품을 동결, 감압함으로 써 얼음을 승화시켜 수분을 제거할 수 있고 원재료의 색, 조직의 유지가 용이하며 복원성이 뛰어나 고품질 농산물 의 건조에 사용되고 있다(Lee 등, 2014; Kim 등, 2015). 진공을 이용하는 감압건조는 과일과 같이 함수율이 높은 식품 건조 시 감압으로 증발 온도를 낮춰 건조시킬 수 있으나, 낮은 열로 인해 미생물이나 효소의 불활성화가 충분하지 않을 경우, 저장 및 유통 중 수분 흡수로 변질될 수 있는 문제점을 동반한다.

최근 과일을 이용한 다양한 형태의 가공품에 대한 수요 가 꾸준히 늘고 있다. 뿐만 아니라, 국내 생산 과일 가격의 안정을 위한 돌파구로 수출, 가공분야의 확대 필요성이 인식, 확산되고 있는 가운데 건조 과실(건과) 스낵 제조업 체가 증가되고 있다(Kim 등, 2013). 배는 대부분 생식용으 로 소비되고 있으며, 가공량은 다른 과종에 비해 실적이 저조해 생산량의 약 $4 \%$ 수준이며(KOSIS, 2017), 그마저도 대부분 음료나 고기양념의 일부로 이용되고 있어 배의 다양한 가공 방법에 관한 연구가 절실한 실정이다.

따라서 본 연구는 배 산업의 활성을 위하여 시도한 건과 제조에 관한 기초 연구로써 상품과 및 소과, 생리장해과 등 비상품과 모두를 이용해 건조 방법에 따른 다양한 배 건과의 품질 특성과 항산화 활성을 측정하여 다양한 공정 방법을 제시하고 가공 소재로써의 이용 가능성을 평가하 고자 하였다.

\section{재료 및 방법}

\section{실험 재료 및 건조방법}

2015년 10월 15일 적숙기에 수확된 '추황배'를 이용하 였다. 건과를 제조하기 위해 과피를 제거하고 $10 \mathrm{~mm}$ 로 슬라이스한 과육을 가열된 공기를 강제 대류시키는 열풍 건조, 감압으로 증발 온도를 낮추는 감압건조, 동결 후 감압 상태에서 얼음을 승화시키는 원리를 이용하는 동결 건조 방법을 이용하였다. 각 건조방법 별 건조 온도 및 시간을 세분화하여 예비 실험한 후, 색도 및 식감을 조사한
결과를 토대로 열풍건조는 열풍건조기(DS-124, Dooritech Co., Ltd., Gwangju, Korea)를 이용하여 $50^{\circ} \mathrm{C}$ 에서 24시간 건 조하였고, 감압건조는 감압건조기(FR/GD08552-M, KyungJin Air System Co., Ltd., Daegu, Korea)를 이용하여 $30^{\circ} \mathrm{C}$ 에 서 35시간 동안 건조하였으며, 동결건조기(PVTFD, Ilshin Lab., Gyeonggi, Korea)로 $-70^{\circ} \mathrm{C}$ 에서 48 시간 동안 동결건 조한 후 배 건과를 제조하였다.

\section{수분함량 및 색도}

수분함량 측정은 각 시료를 $5 \mathrm{~g}$ 씩 취하여 상압가열건조 법으로 측정하였으며, 각 4회 반복 측정하여 나타내었다. 색도 측정은 색차계(CR-400, Minolta Co., Tokyo, Japan)를 이용하여 L*(명도, lightness), a*(적색도, redness), b*(황색 도, yellowness)를 4회 측정하여 평균값과 표준편차로 나타 내었다.

\section{가용성 고형물 및 유리당 분석}

가용성 고형물 함량은 디지털 굴절당도계(Atago Corp., PR-32, Tokyo, Japan)로 측정하여 ${ }^{\circ} \mathrm{Brix}\left({ }^{\circ} \mathrm{Bx}\right)$ 로 표시하였 고, 가용성 당 함량은 HPLC system(Waters Corp., Milford, $\mathrm{MA}, \mathrm{USA})$ 으로 분리 분석하였다. 분쇄한 건과 $1 \mathrm{~g}$ 을 초순 수 물 $10 \mathrm{~mL}$ 에 혼합하여 항온수조에서 1시간 진탕한 후, 원심분리하여 상징액을 회수하였으며, 2회 반복 추출하였 다. Sugar-pak I(Waters Corp., Milford, MA, USA) column을 이용하여 $85^{\circ} \mathrm{C}$ 에서 분석하였으며, refractive index detector 로 검출하였다. 이동상은 HPLC grade의 초순수 물을 사용 하였으며, $0.6 \mathrm{~mL} / \mathrm{min}$ 의 속도로 흘려주었다. Glucose, sucrose, fructose, sorbitol(Chem service, West Chester, PA, USA)을 표준물질로 사용하여 머무름 시간, 스펙트럼을 비교 분석한 후, 검량선으로부터 환산하였다.

\section{총 폴리페놀 및 플라보노이드 함량 분석}

총 폴리페놀 함량은 각 추출물 $0.1 \mathrm{~mL}$ 에 $2 \% \mathrm{Na}_{2} \mathrm{CO}_{3}$ $2 \mathrm{~mL}$ 를 가해 3 분간 실온에서 반응시킨 후, $1 \mathrm{~N}$ FolinCiocalteu's phenol reagent $0.1 \mathrm{~mL}$ 를 첨가하여 빛을 차단한 상태로 다시 실온에서 30 분간 반응시켰으며, 분광광도계 (JP/U-3900, Hitachi, Tokyo, Japan)를 이용하여 $725 \mathrm{~nm}$ 에서 흡광도를 측정하였다. 총 폴리페놀 함량은 tannin acid (T0200, Sigma-Aldrich Corp., Ltd., St. Louis, MO, USA) 표준 액으로 작성한 표준곡선의 흡광도 값과 비교 계산하였다.

총 플라보노이드 함량은 각 추출물 $0.2 \mathrm{~mL}$ 에 diethylene glycol(H26456, Sigma-Aldrich) $2 \mathrm{~mL}, 1 \mathrm{~N} \mathrm{NaOH} 0.2 \mathrm{~mL}$ 를 첨가하여 혼합한 후, $37^{\circ} \mathrm{C}$ 로 조정된 항온수조(VS-190CS, Vision Sci., Daejeon, Korea)에서 1시간 반응시켜 $420 \mathrm{~nm}$ 에 서 흡광도를 측정하였다. Quercetin(Sigma-Aldrich)을 표준 액으로 표준곡선을 작성한 후 총 플라보노이드 함량을 
계산하였다.

\section{$\mathrm{DPPH}$ 라디칼 소거활성 측정}

1,1-Diphenyl-2-picrylhydrazyl(DPPH, Sigma-Aldrich) 라 디칼 소거활성은 Brand-Williams 등(1995)의 방법을 변형 하여 측정하였다. $1 \mathrm{mg} / \mathrm{mL}$ 농도로 제조한 시료 $0.25 \mathrm{~mL}$ 와 $0.15 \mathrm{mM} \mathrm{DPPH}$ 용액 $1 \mathrm{~mL}$ 를 혼합하여 상온에서 30 분간 방치한 다음, $517 \mathrm{~nm}$ 에서 흡광도를 측정하였다. 대조구는 추출물 대신 $80 \%$ 에탄올을 가하여 동일한 방법으로 실험 하였으며, 전자공여능력은 추출물 첨가구와 대조구의 흡 광도를 이용하여 다음 식과 같이 백분율로 표기하였다.

DPPH radical scavenging activity (\%)

$=[1-($ Sample absorbance $/$ Control absorbance $)] \times 100$

\section{$\mathrm{ABTS}$ 라디칼 소거활성 측정}

2,2'-Azino-bis(3-ethylbenzothiazoline-6-sulfonic $\operatorname{acid}(\mathrm{ABTS})$ 라디칼 소거활성의 측정은 $\operatorname{Re}$ 등(1999)의 방 법을 이용하였다. $7 \mathrm{mM} \mathrm{ABTS}$ 와 $140 \mathrm{mM} \mathrm{K} 2 \mathrm{~S}_{2} \mathrm{O}_{8}$ 을 $5 \mathrm{~mL}$ : $88 \mu \mathrm{L}$ 로 섞어 어두운 곳에 12-16시간 방치시킨 후, 이를 absolute ethanol과 1:88의 비율로 섞어 $734 \mathrm{~nm}$ 에서 대조구 의 흡광도 값이 $0.70 \pm 0.02$ 가 되도록 조절한 ABTS solution 을 사용하였다. Methanol에 $20 \mathrm{mg} / \mathrm{mL}$ 의 농도로 맞춘 시료 용액 $50 \mu \mathrm{L}$ 와 ABTS solution $1 \mathrm{~mL}$ 를 30 초 동안 섞은 후 2.5 분간 incubation하여 $734 \mathrm{~nm}$ 에서 흡광도를 측정하였으 며, trolox(Sigma-Aldrich Corp., Ltd., St. Louis, MO, USA)를 표준물질로 사용하여 다음의 식에 의해 계산하였다.

ABTS radical scavenging activity (\%)

$=[1-($ Sample absorbance $/$ Control absorbance $)] \times 100$

\section{페놀화합물 함량 분석}

시료 $1 \mathrm{~g}$ 을 액체 질소에 넣어 마쇄한 후 $20 \mathrm{~mL}$ ethanol로
추출하였다. 추출물은 상온에서 30 분간 ultra-sonication 후 원심분리하고, 상징액을 $0.45 \mu \mathrm{m}$ membrane filter로 여과하 여 HPLC로 분석하였다(LC-20AD, Shimadzu, Kyoto, Japan). 분리용 컬럼은 ACE C18(4.6×250 mm, $5 \mu \mathrm{m}$, Advanced Chromatograph Technologies, Aberdeen, UK)을 이용하였으 며, $25^{\circ} \mathrm{C}$ 에서 $1 \mathrm{~mL} / \mathrm{min}$ 의 유속으로 설정하였다. 이동상은 $\mathrm{A}$ 에 $2 \%$ acetic acid가 포함된 HPLC 등급의 물, $\mathrm{B}$ 에 $0.5 \%$ acetic acid가 포함된 acetonitrile을 사용하였다. 이동상의 조건은 $10 \%(0$ 분 $), 55 \%(0-50$ 분 $), 100 \%(50-60$ 분 $)$, 그리고 $10 \%(60-65$ 분 $)$ 로 설정하여 280 및 $320 \mathrm{~nm}$ 에서 검출하였 다. 표준시약은 arbutin, gallic acid, catechin, chlorogenic acid, caffeic acid, p-coumaric acid, luteolin, quercetin, kaempferol (Sigma-Aldrich Corp., Ltd., St. Louis, MO, USA) 등을 이용하였다.

\section{통계분석}

모든 실험은 4회 반복하였으며, 실험 결과 분석은 SPSS v.20(IBM, Armonk, NY, USA)을 이용하여 일원배치 분산 분석을 실시하였고, Duncan's multiple range test를 이용하 여 집단 간 유의성을 $\mathrm{p}<0.05$ 수준에서 검정하였다.

\section{결과 및 고찰}

\section{수분 함량, 가용성 고형물 함량 및 색도}

건조 방법을 달리한 ‘추황배’ 건과의 수분 함량, 당도 및 색도를 Table 1에 나타내었다. 건조 후 수분 함량은 열풍건조 $14.4 \pm 2.46 \%$, 감압건조 $15.1 \pm 4.84 \%$, 동결건조 $6.3 \pm 1.05 \%$ 로 동결건조, 열풍건조, 감압건조 순으로 낮게 조사되어 동결건조가 건조율이 가장 좋았다. 과일 내 수분 은 보관 시 미생물의 생장 및 증식에 많은 영향을 미치는 것으로 알려져 있는데, 건조된 과일은 대부분의 수분이 제거되므로 미생물의 생장 및 증식에 의한 부패 위험을 낮추는 것이 가능하며(Lee 등, 2014; Piscopo 등, 2014),

Table 1. Moisture content, soluble solid content and color value of 'Chuwhangbae' dried with different methods

\begin{tabular}{|c|c|c|c|c|c|}
\hline \multirow{2}{*}{ Dried type } & \multirow{2}{*}{$\begin{array}{c}\text { Moisture content } \\
(\%)\end{array}$} & \multirow{2}{*}{$\begin{array}{c}\mathrm{SSC}^{1)} \\
\left({ }^{\circ} \mathrm{Brix}\right)\end{array}$} & \multicolumn{3}{|c|}{ Hunter value ${ }^{2)}$} \\
\hline & & & $\mathrm{L}^{*}$ & $a^{*}$ & $b^{*}$ \\
\hline Hot-air & $14.4 \pm 2.46^{\mathrm{b} 3)}$ & $71.4 \pm 3.86^{\mathrm{a}}$ & $73.3 \pm 4.02^{\mathrm{b}}$ & $-0.9 \pm 1.35^{\mathrm{b}}$ & $13.3 \pm 1.36^{\mathrm{b}}$ \\
\hline Vacuum & $15.1 \pm 4.82^{\mathrm{b}}$ & $60.8 \pm 2.27^{\mathrm{b}}$ & $72.9 \pm 2.34^{b}$ & $1.6 \pm 0.51^{\mathrm{a}}$ & $20.2 \pm 1.12^{\mathrm{a}}$ \\
\hline Freeze & $6.3 \pm 1.05^{\mathrm{c}}$ & $69.1 \pm 5.37^{\mathrm{a}}$ & $86.1 \pm 0.93^{\mathrm{a}}$ & $-1.2 \pm 0.25^{\mathrm{b}}$ & $11.1 \pm 0.84^{\mathrm{c}}$ \\
\hline Control $^{4)}$ & $86.7 \pm 2.81^{\mathrm{a}}$ & $13.5 \pm 0.37^{\mathrm{c}}$ & $66.8 \pm 1.99^{c}$ & $-1.3 \pm 0.20^{\mathrm{b}}$ & $6.5 \pm 1.10^{\mathrm{d}}$ \\
\hline
\end{tabular}

${ }^{1)} \mathrm{SSC}$, soluble solid contents.

${ }^{2)} \mathrm{L}^{*}$ (ligheness:0 - 100), a* (green: - 60-red: 60), b* (blue: - 60-yellow:60)

${ }^{3)}$ Means \pm SD $(n=4)$ within each column followed by the different letter are significantly different $(\mathrm{p}<0.05)$.

${ }^{4)}$ Contents before drying the pear flesh. 
그 중에서도 동결건조 방법으로 건과를 제조하는 것이 가장 긍정적인 효과를 보일 것으로 생각된다.

가용성 고형물 함량은 건조 전보다 약 5-6배 증가되어 열풍건조 $71.4{ }^{\circ} \mathrm{Brix}$, 감압건조 $60.8{ }^{\circ} \mathrm{Brix}$, 동결건조 69.1 ${ }^{\circ} \mathrm{Brix}$ 로 건조방법에 따라 다소 차이가 있었다.

Hunter value의 측정은 시각적으로 균일한 색의 측정값 을 제공하기 위한 방법으로 명도를 나타내는 $\mathrm{L}^{*}$ 값은 동결 건조 처리구에서 $86.1 \pm 0.93$ 으로 가장 높았고, 열풍건조 $73.3 \pm 4.02$, 감압건조 $72.9 \pm 2.34$ 순으로 나타났다. 반면, a* 값은 동결건조 처리구에서 $-1.19 \pm 0.25$ 로 가장 낮은 값을 나타냈으며, $\mathrm{b}$ *값 또한 동결건조 처리구가 $11.1 \pm 0.84$ 로 열 풍건조 $13.3 \pm 1.36$, 감압건조 $20.2 \pm 1.12$ 에 비해 상대적으로 낮아 노란빛이 적었다. 이는 동결건조에 비해 높은 온도와 열이 가해지는 건조방법에서 기인된 결과로 chemicalphysical 변화가 색소에 영향을 미첬기 때문이다(Piscopo 등, 2014). 일반적으로 갈변은 peroxidase(POD)와 polyphenol oxidase(PPO)의 효소적 산화에 의해 발생하는 경로와 환원 당과 아미노 화합물간의 특이적인 비효소적 산화로 고분 자량 화합물을 생성하여 갈변 강도에 영향을 주는 경로 두 가지를 들 수 있는데(Yilmaz와 Toledo, 2005; Piscopo 등, 2014), 동결 건조한 건과의 경우, 변색이 거의 없는 것으로 보아 극단적인 저온처리로 인해 효소적, 비효소적 산화 모두 일어나지 않는 것으로 판단된다.

\section{총 당 함량 및 수용성당 조성}

당 분석 결과, 모두 sucrose, glucose, fructose 및 sorbitol 4종의 유리당이 검출되었다(Fig. 1). 열풍건조 및 동결건조 한 과실은 구성당 중 sucrose의 함량이 각각 $35.8 \mathrm{mg} / \mathrm{mL}$ 와 $36.7 \mathrm{mg} / \mathrm{mL}$ 로 높게 조사되었고, 감압건조 과실은 fructose 가 가장 많이 검출되었다. '추황배', '신고', ‘황금배' 생과에 서 수용성당 각각의 함량은 다르지만 fructose, glucose, sucrose, sorbitol의 순으로 함량이 많은 것으로 보고되어 (Yim과 Nam, 2016) 다소 차이가 있는 것을 확인하였다. 특히, sucrose의 함량이 높게 조사된 것은 건과 제조 시의 온도가 sugar metabolic pathway의 sucrose synthase에 영향 을 미쳤을 가능성이 있는 결과로 생각되며(Li 등, 2018),
이는 도라지에서 건조 온도가 높을수록 sucrose 함량이 증가된다는 보고(Lee와 Cho, 2014)와 같은 결과로 볼 수 있다.

\section{총 페놀 및 플라보노이드 함량과 항산화 활성}

총 폴리페놀 함량은 동결건조 $3.12 \mathrm{mg} / \mathrm{g}$, 감압건조 2.2 $\mathrm{mg} / \mathrm{g}$, 열풍건조 $1.97 \mathrm{mg} / \mathrm{g}$ 의 순으로 동결건조 건과에서 총 폴리페놀 함량이 높은 것으로 조사되었으며(Table 2), 오미자, 블루베리, 잣솔잎, 고구마에서도 건조시간 및 추출 온도가 높아질수록 총 폴리페놀 함량이 낮아진다고 보고 하였다(Chung 등, 2013; Lee 등, 2014; Jeong 등, 2015; Shin 등, 2015). 반면 총 플라보노이드 함량은 감압건조한 건과 에서 높았으나 큰 차이는 없었다.

건조 방법을 달리한 '추황배' 건과의 $\mathrm{DPPH}$ 는 감압건조 한 건과에서 $25.4 \%$ 로 가장 높은 활성을 나타내었으며, 다 음으로 동결건조 $21.3 \%$, 열풍건조 $12.1 \%$ 순으로 조사되었 다(Table 2). 일반적으로 식품에 열이 가해졌을 경우, 비타 민 $\mathrm{C}$ 와 같이 열에 약한 물질이 파괴됨으로써 항산화 효능 이 감소한다고 하였으며(Chang과 Kim, 2011), 본 실험에서 도 높은 열이 가해진 열풍건조의 항산화 활성이 상대적으 로 낮게 조사되었다.

$\mathrm{ABTS}$ 라디칼 소거 활성은 동결건조 $19.9 \%$ 로 가장 높은 활성을 나타냈으며, 감압건조 $15.5 \%$, 열풍건조 $11.0 \%$ 로 조사되었다. ABTS 라디칼 소거는 극성과 비극성 시료의 소거 활성 모두 측정할 수 있으므로 DPPH 라디칼 소거보 다 적용범위가 넓은 것으로 알려져 있으나, 본 실험결과 $\mathrm{ABTS}$ 라디칼 소거 활성이 더 낮은 것으로 조사되었다. 이는 추출물의 특성에 따라 자유라디칼 및 생성된 양이온 과의 결합 정도가 다를 수 있으므로 두 기질과 반응물과의 결합 정도가 상이했기 때문에 라디칼 제거 능력에도 차이 가 생겼을 것으로 생각되며(Rice-Evans 등 1996; Lee 등, 2014; Yim 등, 2016), 건조하는 과정 중 발생하는 열 또는 저온에 의해 영향을 받은 것으로 판단된다. 또한, 건조한 블루베리에서도 건조온도가 낮을수록 항산화 활성이 높 고, 총 폴리페놀 함량이 증가할수록 $\mathrm{DPPH}$ 라디칼 소거 활성이 증가하여 서로 상관관계가 있다고 해석하였으며

Table 2. Antioxidant component and radical scavenging activity of 'Chuhwangbae' dired with different methods

\begin{tabular}{ccccc}
\hline Dried type & $\begin{array}{c}\text { Total polyphenol } \\
(\mathrm{mg} / \mathrm{g})\end{array}$ & $\begin{array}{c}\text { Total flavonoid } \\
(\mathrm{mg} / \mathrm{g})\end{array}$ & $\begin{array}{c}\text { DPPH } \\
(\%)\end{array}$ & $\begin{array}{c}\text { ABTS } \\
(\%)\end{array}$ \\
\hline Hot-air & $1.97 \pm 0.06^{\mathrm{c} 1)}$ & $0.26 \pm 0.01^{\mathrm{b}}$ & $12.1 \pm 1.85^{\mathrm{b}}$ & $11.0 \pm 0.61^{\mathrm{c}}$ \\
Vacuum & $2.20 \pm 0.37^{\mathrm{b}}$ & $0.29 \pm 0.02^{\mathrm{a}}$ & $25.4 \pm 1.61^{\mathrm{a}}$ & $15.5 \pm 0.49^{\mathrm{b}}$ \\
Freeze & $3.12 \pm 0.02^{\mathrm{a}}$ & $0.28 \pm 0.00^{\mathrm{ab}}$ & $21.3 \pm 3.58^{\mathrm{a}}$ & $19.9 \pm 0.94^{\mathrm{a}}$ \\
\hline
\end{tabular}

${ }^{1)}$ Means \pm SD $(\mathrm{n}=4)$ within each column followed by the different letter are significantly different $(\mathrm{p}<0.05)$.

${ }^{2)}$ Contents before drying the pear flesh. 
Table 3. Phenolic compositions of 'Chuhwangbae' dried with different methods

\begin{tabular}{ccccc}
\hline Dried type & $\begin{array}{c}\text { Arbutin } \\
(\mu \mathrm{g} / \mathrm{g})\end{array}$ & $\begin{array}{c}\text { Catechin } \\
(\mu \mathrm{g} / \mathrm{g})\end{array}$ & $\begin{array}{c}\text { Chlorogenic acid } \\
(\mu \mathrm{g} / \mathrm{g})\end{array}$ & $\begin{array}{c}\text { Gallic acid } \\
(\mu \mathrm{g} / \mathrm{g})\end{array}$ \\
\hline Hot-air & $303.56 \pm 7.71^{\mathrm{a} 1)}$ & $183.32 \pm 0.87^{\mathrm{a}}$ & $320.51 \pm 2.96^{\mathrm{a}}$ & $129.73 \pm 1.73^{\mathrm{a}}$ \\
Vacuum & $193.36 \pm 6.16^{\mathrm{c}}$ & $148.30 \pm 0.61^{\mathrm{c}}$ & $178.15 \pm 1.08^{\mathrm{c}}$ & $122.24 \pm 0.88^{\mathrm{c}}$ \\
Freeze & $244.74 \pm 2.79^{\mathrm{b}}$ & $170.56 \pm 1.71^{\mathrm{b}}$ & $267.37 \pm 1.86^{\mathrm{b}}$ & $125.53 \pm 0.77^{\mathrm{b}}$ \\
\hline
\end{tabular}

${ }^{1)}$ Means \pm SD $(n=4)$ within each column followed by the different letter are significantly different $(\mathrm{p}<0.05)$.

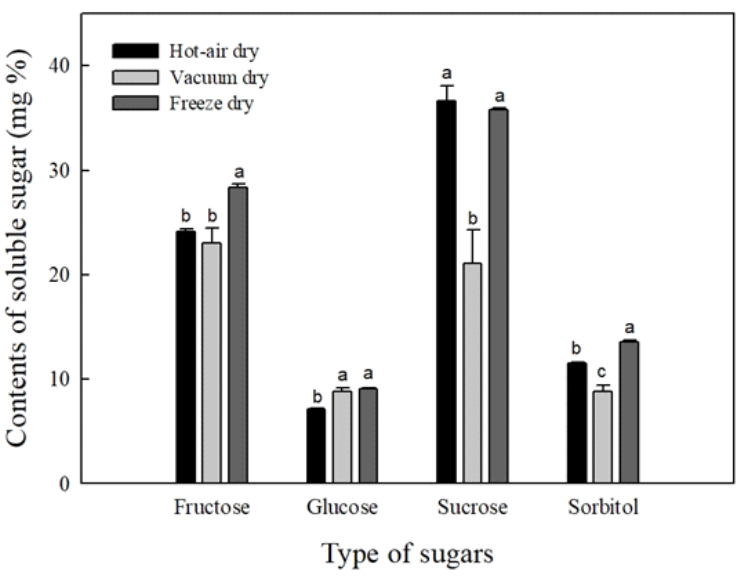

Fig. 1. Soluble sugars content of 'Chuwhangbae' dried with different methods.

The date represent the mean $\pm \mathrm{SD}(\mathrm{n}=4)$. Means with different letter are significantly different $(\mathrm{p}<0.05)$.

(Shin 등, 2015), 이는 본 연구결과와도 일치하였다.

\section{페놀화합물 성분별 분리 분석}

건조 방법을 달리한 ‘추황배’ 추출물의 페놀화합물을 분석한 결과(Table 3), 모두 arbutin, catechin, chlorogenic acid, gallic acid 4종의 페놀화합물이 검출되었다. 열풍, 감 압 및 동결건조 방법별 페놀화합물의 함량은 각각 937.12 , 642.05 및 $808.20 \mu \mathrm{g} / \mathrm{g}$ 으로 열풍건조가 다른 건조방법에
비해 유의하게 높은 함량을 나타내었는데, 과일 또는 채소 류의 가열처리는 세포 내 셀룰로오스 구조를 붕괴시켜 생리활성을 나타내는 물질의 이용성을 증가시킬 수 있다 고 하였다(Hof 등, 2000; Seo 등, 2018).

Yim과 Nam(2016)은 '추황배' 생과에서 arbutin, catechin, chlorogenic acid, gallic acid 및 caffeic acid가 검출되었다고 보고하였는데, 건과에서는 생과에서 검출되던 caffeic acid 가 검출되지 않는 특이점을 발견하였다. 특히, caffeic acid는 chlorogenic acid 합성이나 lignin 합성에 사용되는 핵심물질 로 사과, 체리, 복숭아에서도 가열로 인한 caffeic acid의 손실 을 보고한 바 있으나(Szwajgier 등, 2014), 본 연구에서는 건조 온도가 낮은 동결건조 처리구에서도 검출되지 않았기 때문에 어떠한 요인에 의해 caffeic aicd가 검출되지 않은 것인지는 추후 자세한 검토가 필요할 것으로 생각된다.

\section{생리장해과의 건과 특성}

동양배에 발생하는 생리장해에는 과피 흑변, 과심 및 과육 갈변, 바람들이, 수침현상 등이 있다(Hwang 등, 2001; Lee 등, 2014). ‘추황배'에서는 특히, 과피흑변과 과육갈변 이 흔히 발생하는데, 그중 과육 갈변은 저장 중 과육의 일부 조직이 갈변된 후 증상이 진전되며 갈변 부위의 조직 이 붕괴되는 장해를 말한다(Choi, 1999). 이러한 생리장해 과는 생식용으로써의 상품적 가치가 상실되므로 과육갈 변과를 이용하여 상품성 있는 건과 생산이 가능할 것인지
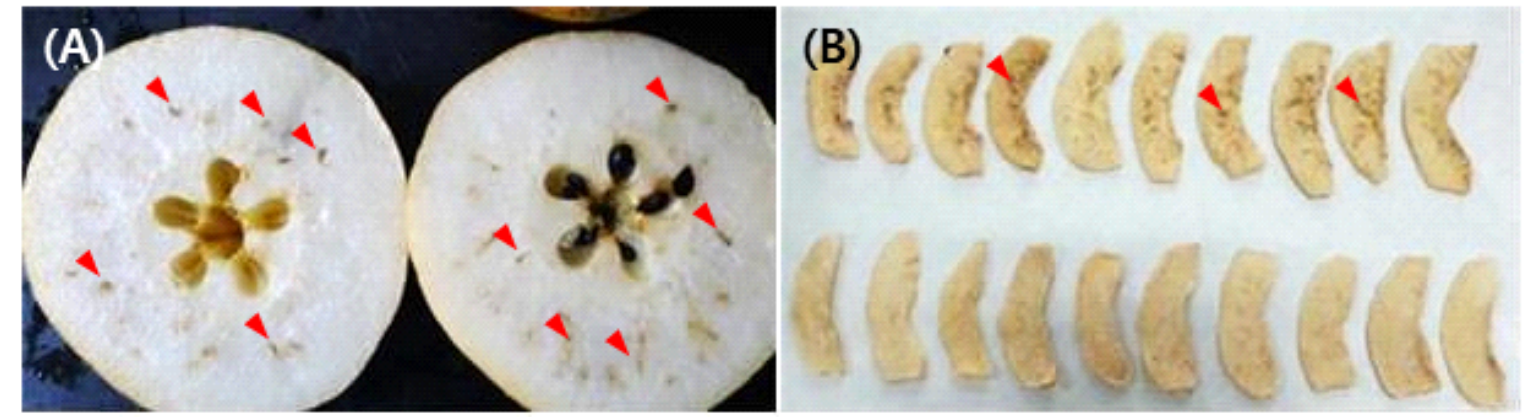

Fig. 2. Cross section of flesh browning disorder fruit (A) and dried fruit (B; upper dried fruit is flesh browning disorder fruit and lower dried fruit is normal fruit).

Flesh browning spot (arrow) in disorder fruit. 
평가하였다. 그 결과, 정상과로 건조한 건과와 비교했을 때 수분함량, 당도, 색도 등 기본적인 품질에서는 큰 차이 가 없었으나, 갈변된 부분이 더 선명해져 외관상 보기 좋지 않았다(Fig. 2). 따라서 이는 잘게 잘라 떡이나 빵, 파우더 제작 등 가공식품의 부재료로 활용이 가능할 것으로 판단 되었다. 또한 '신고' 위주의 편중재배로 비슷한 시기의 홍수 출하, 특정 병충해 발생으로 인한 비상품과 발생, 저장기간 중 생리장해 등 여러 문제가 발생되고 있는데, 이를 이용한 건과 제조로 배 재배농가의 소득 안정화에도 기여할 수 있을 것이다.

\section{요 약}

본 연구는 배 산업 활성화를 위한 배 건과 제조에 관한 연구로써 ‘추황배' 상품과 및 비상품과 모두를 이용해 건 조 방법에 따른 건과의 품질 특성과 항산화 활성을 측정하 였다. 수분함량은 건조온도가 낮을수록 유의적으로 적은 것으로 나타났다. 색도를 측정한 결과, $\mathrm{L} *$ 값은 건조온도가 낮은 동결건조에서 높게 조사된 반면, $\mathrm{a}^{*}$ 및 $\mathrm{b}^{*}$ 값의 경우에 는 비교적 건조온도가 높은 열풍, 감압건조에서 높게 조사 되어 노란빛을 띄어 약간의 갈변이 진행되었다. 수용성당 은 열풍 및 동결건조한 건과에서는 sucrose의 함량이 가장 높았고, 감압건조에서는 fructose가 가장 많이 검출되었다. 총 폴리페놀 함량은 건조 온도가 높을수록 낮게 조사되었 으나, 총 플라보노이드 함량은 건조방법에 따른 큰 차이가 없었다. 건과의 페놀화합물 분리분석 시 arbutin, catechin, chlorogenic acid, gallic acid 4종이 검출되었으며, 열풍건조 가 다른 건조방법에 비해 유의하게 함량이 많았다. 생리장 해과를 이용해 건과 생산 시 품질에서는 상품과와 차이가 없었으나, 생리장해 부분이 갈색으로 선명해져 가공식품 의 부재료로 사용해야 할 것으로 판단된다. 또한, 각 건조 방법에 따라 색, 성분, 식감 등에 대한 영향이 다르므로 용도에 맞는 건조방법을 사용하여 장기간 저장 가능한 다양한 건과 제조가 가능하며, 비상품과를 활용한 가공으 로 침체된 배 산업 활성화 및 농가 소득 증대에 일부 기여할 수 있을 것으로 생각된다.

\section{감사의 글}

본 연구는 농촌진흥청 기본연구사업(PJ00689403, 배 고 당도 품종 조기선발 기술 개발)의 지원에 의해 수행되었으 며, 이에 감사드립니다.

\section{Conflict of interests}

The authors declare no potential conflict of interest.

\section{ORCID}

YoSup Park https://orcid.org/0000-0001-5762-1033

References

Bennett LE, Jegasothy H, Konczak I, Frank D, Sudharmarajan S, Clingeleffer PR. Total polyphenolics and anti-oxidant properties of selected dried fruits and relationships to drying conditions. J Func Food, 3, 115-124 (2011)

Brand-Williams W, Cuvelier ME, Berset C. Use of free radical method to evaluate antioxidant activity. LWTFood Sci Technol, 28, 25-30 (1995)

Chang Y, Kim J. Effects of pretreatment and drying methods on the quality and physiological activities of garlic powders. J Korean Soc Food Sci Nutr, 40, 1680-1687 (2011)

Choi SJ. Physiological properties related to flesh browning in 'Fuji' apple fruit. J Kor Soc Hort Sci, 38, 250-254 (1997)

Chung HS, Kim IH, Kim SH, Lee JH. Antioxidant properties of Pinus koraiensis needle powder extracts as influenced by drying methods. Food Eng Prog, 17, 396-400 (2013)

Hof KH, de Boer BC, Tijburg LB, Lucius BR, Zijp I, West CE, Hautvast JG, Weststrate JA. Carotenoid bioavailability in humans from tomatoes processed in different ways determined from the carotenoid response in the triglyceride-rich lipoprotein fraction of plasma after a single consumption and in plasma after four days of consumption. J Nutr, 130, 1189-1196 (2000)

Hwang YS, Chun JP, Lee JC, Seo JH. Storage response of 'Kamchun' and 'Chuhwang' pears by harvest dates. Kor J Hort Sci Technol, 19, 48-53 (2001)

Jeong DW, Park YK, Nam SS, Han SK. Effect of hot-air drying temperature on antioxidant activity of sweet potato leaves. Korean J Food Preserv, 22, 708-713 (2015)

Kim AR, Lee HJ, Jung HO, Lee JJ. Physicochemical composition of ramie leaf according to drying methods. J Korean Soc Food Sci Nutr, 43, 118-127 (2014)

Kim GC, Lee SY, Kim KM, Kim Y, Kim JS, Lim HR. Quality characteristics of hot-air and freeze dried apples slices after osmotic dehydration. J Korean Soc Food Sci Nutr, 40, 848-852 (2011)

Kim HJ, Park BG, Han I. Effect of drying and extraction methods on antioxidant activity of Gnaphalium affine D. 
Don. J Korean Soc Food Sci Nutr, 44, 695-701 (2015)

Kim YK, Kang SS, Won KH, Lee HC, Choi JJ, Choi JH, Yim SH. Main characteristics of freezing dried fruit in pear cultivars. Kor J Hort Sci Technol, 31, 125-126 (2013)

KOSIS. Fruit Processing List. National Statistics. Korea (2017)

Lee BJ, Cho YS. Effects of drying temperature on the saponin and free sugar contents of Platycodon grandiflorum Radix. Kor J Food Sci Technol, 46, 769-772 (2014)

Lee S, Moon HK, Lee SW, Moon JN, Kim JK. Effects of drying methods on quality characteristics and antioxidative effects of Omija (Schizandra chinensis Bailon). Korean J Food Preserv, 21, 341-349 (2014)

Lee UY, Oh KS, Choi JH, Ahn YJ, Chun JP. Changes of fruit quality and reduction of physiological disorders during shelf-life in early-season pear (Pyrus pyrifolia Nakai) fruits treated with aminoethoxyvinylglycine. Kor J Hort Sci Technol, 32, 193-201 (2014)

Li M, Li P, Ma F, Dandekar AM, Cheng L. Sugar metabolism and accumulation in the fruit of transgenic apple trees with decreased sorbitol synthesis. Hortic Res, 5, 60 (2018)

Piscopo A, De Bruno A, Zappia A, Poiana M. Antioxidant activity of dried green olive (Carolea cv.). LWT - Food Sci Technol, 58, 49-54 (2014)

Re R, Pellegrini N, Proteggente A, Pannala A, Yang M, Rice-Evans C. Antioxidant activity applying an improved ABTS radical cation decolorization assay. Free Radical Bio Med, 26, 1231-1237 (1999)

Rice-Evans CA, Miller NJ, Paganga G. Structure-antioxidant activity relationships of flavonoids and phenolic acids. Free Radical Biol Med, 20, 933-956 (1996)

Seo BY, Kim JS, Park E. Comparison of phenolic compounds and antioxidant properties of sweet potato (Imopea batatas L. Lam) according to variety and moist heat cooking. J Korea Soc Food Sci Nutr, 47, 243-252 (2018)

Shin DS, Yoo YM, Kim HY, Han GJ. Determine the effects of drying temperature on the quality change and antioxidant activity characteristics of blueberry. Korean J Food Preserv, 22, 505-511 (2015)

Szwajgier D, Halinowski T, Helman E, Tylus K, Tymcio A. Influence of different heat treatment on the content of phenolic acid and their derivatives in selected fruit. Fruit, 69, 167-178 (2014)

Yilmaz Y, Toledo R. Antioxidant activity of water-soluble maillard reaction products. Food Chem, 93, 273-278 (2005)

Yim SH, Cho KS, Choi JH, Lee JH, Kim MS, Lee B. Effect of various pear cultivars at different fruit development stages on antioxidant and whitening activities. Korean J Food Sci Technol, 48, 59-65 (2016)

Yim SH, Nam SH. Physiochemical, nutritional and functional characterization of 10 differennt pear cultivars (Pyrus spp.). J Appl Bot Food Qual, 89, 73-81 (2016)

Youn KS, Kim JW. Antioxidant and angiotensin converting enzyme I inhibitor activities of extracts from mulberry (Cudrania tricuspidata) fruit subjected to different drying methods. J Korean Soc Food Sci Nutr, 41, 1388-1394 (2012) 